\title{
KEMAMPUAN MENCERITAKAN KEMBALI CERITA ANAK OLEH SISWA KELAS VII MTS PROYEK KANDEPAG MEDAN
}

\author{
Ririn Susmita \\ Pendidikan Bahasa dan Sastra Indonesia \\ PPs Universitas Negeri Medan
}

\begin{abstract}
Abstrak, Tujuan penelitian ini adalah untuk mengetahui kemampuan menceritakan kembali cerita anak oleh siswa kelas VII MTs Proyek Kandepag Medan Tahun Pembelajaran. Lokasi penelitian adalah MTs Proyek Kandepag Medan Tahun Pembelajaran. Populasi penelitian ini adalah siswa kelas VII MTs Proyek Kandepag Medan Tahun Pembelajaran yang berjumlah 74 siswa yang terdiri dari 2 kelas. Sampel dalam penelitian ini adalah kelas VIII dan VII2 dengan jumlah siswa sebanyak 74 orang. Teknik pengumpulan data yang digunakan dalam penelitian ini yaitu dengan menggunakan tes essai. Metode yang digunakan dalam penelitian ini adalah metode deskriftif yaitu metode yang bertujuan untuk mendeskripsikan secara sistematis untuk mengetahui kemampuan yang dimiliki siswa dalam menceritakan kembali cerita anak oleh siswa kelas VII MTs Proyek Kandepag Medan. Hasil pengelolahan data yang dilakukan dari 74 siswa. 36 siswa yang memiliki nilai 66-79 (baik, 48\%) dengan nilai 70. 19 siswa yang memiliki nilai 40-55 (kurang, 26\%) dengan nilai 50, 19 siswa yang memiliki nilai 0-39 (gagal, 26\%) dengan nilai 30. Dari penelitian ini, dapat diketahui nilai rata-rata seluruh siswa yang berjumlah 74 siswa dari kemampuan menceritakan kembali cerita anak hasil observasi adalah 81,09.
\end{abstract}

Kata Kunci: Kemampuan Menceritakan Kembali, Cerita Anak

\section{PENDAHULUAN}

Berbahasa ada empat komponen pemerolehan bahasa dengan cara yang beraneka-ragam. Mula-mula pada masa kecil kita belajar menyimak bahasa, kemudian berbicara, sesudah itu kita belajar membaca dan menulis. Keempat keterampilan tersebut pada dasarnya merupakan suatu kesatuan, merupakan catur tunggal.

Menceritakan kembali pada hakikatnya adalah suatu proses kegiatan berbahasa, sebab terjadinya pemindahan pesan dari komunikator kepada komunikan. Wujud kegiatan ini dapat dilihat, misalnya guru menjelaskan pelajaran kepada siswa. 
Kegiatan menceritakan kembali atau mengulangi suatu materi merupakan proses yang membutuhkan pemahaman dan kompetensi kebahasaan. Dalam menceritakan kembali cerita anak, keempat komponen keterampilan berbahasa sangat berpengaruh guna tercapainya kompetensi tersebut. Keterampilan ini sendiri bagi siswa merupakan salah satu keterampilan berbahasa yang penting untuk dikuasai karena bila siswa dapat menguasai keterampilan ini dengan baik akan memudahkannya dalam berkomunikasi dan mengungkapkan ide atau gagasan kepada orang lain.

$$
\text { Pembelajaran kemampuan }
$$

menceritakan kembali cerita anak oleh siswa sangat dituntut untuk mencapai kompetensi yang diharapkan. Menceritakan kembali teks cerita merupakan kegiatan untuk menyampaiki.-apa yang telah dibaca dan menemukan pokok-pokok dalam cerita tersebut. Menceritakan kembali dikatakan baik apabila isi pembicaraan dipahami oleh pembaca dan pendengar. Apabila dituliskan kembali, pola yang sudah di temukan dapat menemukan poko-pokok dalam cerita yang telah dibaca . Pola itu juga tampil dalam kata yang digunakan, disusun secara konkret dan lugas. Apabila hal ini terwujud, pencerita mampu menceritakan isi cerita secara umum, nyata, jelas, dan konkret secara tulisan. Begitu juga sebaliknya bagi pendengar dengan mudah menafsirkan isi cerita tersebut.

Kurikulum Tingkat Satuan Pendidikan (KTSP), khususnya pada kompetensi dasar "Menceritakan kembali cerita anak yang dibaca", implementasi yang diharapkan dari komptensi dasar tersebut adalah siswa mampu menceritakan kembali cerita yang telah dibaca atau didengarnya dengan bahasa sendiri secara tulisan atau lisan. Dalam hal ini, berarti kemampuan siswa sangat dituntut guna tercapainya kompetensi tersebut. Namun, kenyataannya di lapangan sangat berbeda dengan hal yang diharapkan karena masih ada sejumlah siswa yang masih kurang dalam pembelajaran ini, seperti siswa kurang mampu menceritakan kembali cerita anak secara runtun, dalam menceritakan kembali ada bagian cerita yang hilang, muncul cerita baru atau jalan cerita berubah tidak sesuai dengan cerita sebenarnya, jalan cerita yang awalnya panjang menjadi pendek.

Berdasarkan latar belakang masalah tersebut peneliti tertarik untuk melakukan penelitian meningkatkan kemampuan menceritakan kembali cerita anak. Berdasarkan hal itu, peneliti mengambil judul Kemampuan Menceritakan Kembali Cerita Anak oleh 
Siswa Kelas VII MTs Proyek Kandepag Medan.

Pelaksanaan penelitian dapat dilakukan dengan baik apabila rumusan masalahnya jelas. Hal ini dimaksud agar peneliti lebih terarah pada suatu sasaran. Rumusan masalah yang akan diteliti dalam penelitian ini adalah 'Bagaimana kemampuan menceritakan kembali cerita anak oleh siswa kelas VII ? Berdasarkan rumusan masalah, tujuan penelitian adalah untuk mengetahui kemampuan menceritakan kembali cerita anak oleh siswa kelas VII MTs Proyek Kandepag Medan Tahun Pembelajaran .

KBBI (2007:707) dikatakan "mampu berarti kuasa, sanggup melakukan sesuatu', sedangkan kemampuan berarti kesanggupan dan kekuatan kita untuk berusaha melakukan dengan diri sendiri',. Sedangkan menurut Tarigan (1986:3), “Kompetensi atau kemampuan adalah pengetahuan yang mempunyai pemakaian bahasa tent 5 bahasanya dan inilah yang merupakan objek penting".

Kemampuan adalah kesanggupan atau kecakapan yang dimiliki sesorang melalui latihan. Kemampuan sangat identik dengan keterampilan, untuk mempertahankan tingkat perhatian yang tinggi diperlukan latihan yang terus menerus dapat dikatakan memiliki kemampuan dibidang yang ditekuni.

Bercerita merupakan salah satu kemampuan yang diturunkan dari aspek berbicara. Aspek berbicara ini merupakan salah satu dari empat jenis keterampilan berbahasa yang diajarkan di sekolah, yakni keterampilan menyimak, keterampilan berbicara, keterampilan membaca, dan keterampilan menulis. Keterampilan berbicara sendiri menurut Tarigan (1981:3) merupakan "suatu keterampilan berbahasa yang berkembang pada kehidupan anak, yang hanya didahului oleh keterampilan menyimak, pada masa tersebutlah kemampuan berbicara baru dipelajari”.

Nurhadi, dkk (2007:54) dalam menilai kriteria kemampuan menceritakan sebuah teks cerita harus dilihat dari segi kesesuaian isi cerita.

Pengertian berbicara, kegiatan bercerita (menceritakan) dapat dilakukan siswa untuk mengasah keterampilan berbahasanya, memperbanyak perbendaharaan katanya sebab kegiatan bercerita (menceritakan) ini melatih anak untuk dapat berkomunikasi dengan orang lain melalui cerita yang disampaikannya. Hal ini sejalan dengan yang dikatakan Mursini (2011:188) bahwa cerita, mendengarkan radio, dan bercerita adalah aspek yang sangat penting dalam pemerolehan bahasa, keakraban anak pada 
bentuk-bentuk cerita merupakan nilai penting dalam proses pemerolehan bahasa, pengalaman anak yang diperoleh dengan mendengarkan cerita dapat memperkaya perbendaharaan kata.

Menceritakan dapat diartikan dengan menuturkan cerita ataupun sesuatu hal, misalnya terjadinya sesuatu, kejadian yang sesungguhnya terjadi ataupun yang rekaan, atau lakon yang terwujud dalam gambar. Menceritakan dapat berfungsi sebagai sarana untuk menyampaikan pesan berupa penjelasan, gambaran, sesuatu hal, menghibur, keterampilan berbicara, interaksi antara pembicaraan dan pendengar dalam kegiatan bercerita berjalan searah. Pembicaranya menyampaikan pesan sedangkan pendengar menerima pesan tanpa dapat berinteraksi langsung kepada pembicara. Oleh karena itu, interaksi antara pembicara dan pendengar dalam kegiatan disebut satu arah.

Menceritakan menjadi sangat penting dalam proses pemerolehan bahasa karena melalui bercerita anak-anak dapat mengolah kembali semua bentuk pengalaman mereka dalam bahasa. Melatih anak untuk bercerita berarti melatih mereka untuk berani berbicara di depan orang lain. Dengan bercerita, atau merangkai peristiwa dalam ujaran, anakanak memeroleh kesempatan mengungkapkan hal yang sudah terjadi, menyampaikan apa yang sedang terjadi. Dengan bercerita, anak-anak juga belajar menyesuaikan persepsinya orang lain pada saat yang sama, anak-anak lain berlatih untuk menyimak cerita. Keterampilan ini tampaknya mudah, namun dalam pelaksanaannya dapat menjadi sulit dimulai. Disinilah peran guru untuk mendorong agar anak belajar menghormati orang yang sedang berbicara.

Mursini (2010:117) Cerita anak ialah cerita yang ditulis untuk anak dan berbicara mengenai kehidupan anak dan sekeliling yang mempengaruh anak serta cerita itu hanya dapat dinikmati oleh anak dengan bantuan dan pengarahan orang dewasa. Cerita anak juga meruapakan salah satu jenis sastra anak yang dikembangkan dalam bentuk fiksi. Bentuk penulisan dari fiksi adalah prosa, yaitu karangan yang ditulis secara prosais, bentuk uraian dengan kalimat relatif panjang dalam bentuk narasi.

Mursini (2010:146) "Sebuah cerita fiksi pada dasarnya terdiri dari atas unsur intrinsik dan ekstrinsik. Unsur intrinsik adalah unsur-unsur dalam cerita fiksi yang secara langsung berada di dalam bangunan cerita, menjadi bagian terpenting, dan sangat adil dalam membentuk eksistensi cerita yang akan diwujudkan. Unsur-unsur intrinsik dalam prosa fiksi antara lain : tema, alur cerita, amanat, sudut pandang, latar cerita, penokohan/perwatakan, dan 
gaya bahasa. Sedangkan unsur ekstrinsik yaitu permasalahan kehidupan, falsafah, cita-cita, ide-ide, dan gagasan serta latar budaya yang menopang kisahan cerita dan unsur intrinsik (unsur dalam dari sebuah fiksi)."

\section{Tema}

Mursini (2010:146) menjelaskan bahwa tema adalah ide sentral yang mendasari suatu cerita. Secara sederhana tema adalah makna cerita, gagasan atau ide yang mendasari sebuah cerita.

Tema mempunyai tiga fungsi, yaitu: sebagai pedoman bagi pengarang dalam menggarap cerita, sasaran/tujuan penggarapan cerita, dan mengikat peristiwa dalam suatu alur.

Cerita anak tema dapat diwujudkan secara implisit atau eksplisit. Perwujudan tema secara implisit (tersirat) maksudnya tema cerita tersembunyi atau tersirat dalam isi cerita, sehingga untuk menemukan tema membaca cerita dengan cermat. Sedangkan perwujudan tema secara eksplisit (tersurat).

\section{Alur atau Plot}

Alur atau plot adalah "struktur gerak yang terdapat dalam fiksi atau drama” Brooks dalam Tarigan (1985:126). Sebuah cerita merupakan rangkaian peristiwa, dan peristiwa yang dirangkaikan itu merupakan susunan dari kejadiankejadian yang lebih kecil.

\section{Perwatakan/Penokohan}

Mursini (2010:150) penokohan adalah pelukisan tokoh/pelaku cerita melalui sifat-sifat, sikap dan tingkah lakunya dalam cerita. Sifat menyeluruh dari manusia yang disorot, termasuk perasaan, cara berpikir, cara bertindak dan sebagainya.

\section{Latar atau Setting}

Latar atau Setting merupakan situasi tempat, ruang, dan waktu terjadinya cerita. Tercakup didalamnya lingkungan geografis, rumah tangga, pekerjaan, bendabenda dan alat-alat yang berkaitan dengan tempat terjadinya peristiwa cerita.

\section{Amanat}

Amanat dapat diartikan pesan berupa ide, gagasan, ajaran moral dan nilai-nilai kemanusian yang ingin disampaikan atau dikemukakan pengarang lewat cerita.

\section{METODE PENELITIAN}

Penelitian ini dilakukan di MTs Proyek Kandepag Medan Jl. Yos Sudarso KM. 13,5 Simp. Atap Martubung. Alasan peneliti menetapkan sekolah tersebut sebagai lokasi penelitian. Populasi dalam penelitian ini adalah seluruh siswa kelas VII MTs Proyek Kandepag Tahun Pembelajaran. Berdasarkan peninjauan yang dilakukan, diperoleh data seluruh siswa kelas VII berjumlah 74 siswa tersebar atas 2 kelas. jika jumlah 
subjeknya besar dapat diambil 10-15\% atau $20-25 \%$ atau lebih. Karena kurang dari 100, jadi seluruh siswa dijadikan sampel atau total sampel yang berjumlah 74 siswa. Adapun kelas yang dijadikan sampel adalah kelas VII MTs Proyek
Kandepag Medan. Metode dalam penelitian ini adalah metode deskriptif yang digunakan untuk melihat bagaimana kemampuan siswa menceritakan kembali cerita anak.

\section{HASIL DAN PEMBAHASAN}

Sebagaimana telah diuraikan pada bagian metode penelitian, bahwa alat yang digunakan untuk mengumpulkan data adalah tes essay. Setelah dilakukan penelitian terhadap siswa kelas VI MTs Proyek Kandepag Medan tentang kemampuan menceritakan kembali cerita anak, penelitian ini memperoleh data yang selanjutnya diolah menjadi beberapa tahap.

\section{Tabel Kerja Mencari Nilai Akhir}

\begin{tabular}{|c|l|c|c|}
\hline No. & \multicolumn{1}{|c|}{ Skala Sigma } & Skala Nilai & Skor Nilai \\
\hline 1. & $2,25 \mathrm{SD}$ & 100 & $81,09+(2,25 \times 6,43)=96$ \\
\hline $\mathbf{2 .}$ & $1,75 \mathrm{SD}$ & 90 & $81,09+(1,75 \times 6,43)=92$ \\
\hline $\mathbf{3 .}$ & $1,25 \mathrm{SD}$ & 80 & $81,09+(1,25 \times 6,43)=89$ \\
\hline $\mathbf{4 .}$ & $0,75 \mathrm{SD}$ & 70 & $81,09+(0,75 \times 6,43)=86$ \\
\hline $\mathbf{5 .}$ & $0,25 \mathrm{SD}$ & 60 & $81,09+(0,25 \times 6,43)=83$ \\
\hline $\mathbf{6 .}$ & $-0,25 \mathrm{SD}$ & 50 & $81,09+(-0,25 \times 6,43)=79$ \\
\hline $\mathbf{7 .}$ & $-0,75 \mathrm{SD}$ & 40 & $81,09+(-0,75 \times 6,43)=76$ \\
\hline $\mathbf{8 .}$ & $-1,25 \mathrm{SD}$ & 30 & $81,09+(-1,25 \times 6,43)=73$ \\
\hline
\end{tabular}




\begin{tabular}{|c|l|c|c|}
\hline 9. & $-1,75 \mathrm{SD}$ & 20 & $81,09+(-1,75 \times 6,43)=70$ \\
\hline $\mathbf{1 0 .}$ & $-2,25 \mathrm{SD}$ & 10 & $81,09+(-2,25 \times 6,43)=67$ \\
\hline
\end{tabular}

Berdasarkan tabel tersebut, maka dapat ditentukan nilai akhir siswa sesuai dengan skor mentah yang diperolehnya. Untuk lebih jelasnya dapat dilihat pada tabel berikut :

Persentase Nilai Akhir Siswa

\begin{tabular}{|l|c|c|c|c|}
\hline No. & Nilai & Frekuensi & Persentase & Kategori \\
\hline 1. & $80-100$ & - & - & - \\
\hline 2. & $66-79$ & $36 \div 74 \times 100=48$ & $48 \%$ & Baik \\
\hline 3. & $56-65$ & - & - & - \\
\hline 4. & $40-55$ & $19 \div 74 \times 100=26$ & $26 \%$ & Kurang \\
\hline 5. & $0-39$ & $19 \div 74 \times 100=26$ & $26 \%$ & Gagal \\
\hline & Jumlah & $\mathbf{7 4}$ & $\mathbf{1 0 0 \%}$ & \\
\hline
\end{tabular}

Berdasarkan tabel tersebut, dapat disimpulkan hasil tes kemampuan menceritakan kembali cerita anak adalah sebagai berikut: Siswa yang memiliki nilai 80-100 (baik sekali) tidak ada, siswa yang memiliki nilai 66-79 (baik) sebanyak 36 siswa $(48 \%)$, siswa yang memiliki nilai
56-65 (cukup) tidak ada, siswa yang memiliki nilai 40-55 (kurang) sebanyak 19 siswa (26\%) dan siswa yang memiliki nilai 0-39 (gagal) sebanyak 19 siswa (26\%).

Secara ringkas, hasil perhitungan untuk masing-masing variable dapat dirangkum sebagai berikut : 


\section{Ringkasan Hasil Perhitungan}

\begin{tabular}{|c|c|c|}
\hline No. & Statistik & Jumlah \\
\hline 1. & $\mathrm{~N}$ & 74 \\
\hline 2. & Jumlah Nilai & 6001 \\
\hline 3. & Mean (Rata-rata) & 81,09 \\
\hline 4. & Standar Deviasi & 6,43 \\
\hline 5. & Maksimum & 86 \\
\hline 6. & Minimum & 62 \\
\hline
\end{tabular}

Berdasarkan hasil penelitian kemampuan menceritakan kembali cerita anak 36 siswa (48\%) mendapat nilai 66-79 dengan nilai rata-rata 70 . Berdasarkan penelitian ini diketahui hasil pembelajaran Bahasa Indonesia khususnya mengenai kemampuan menceritakan kembali cerita anak oleh siswa kelas VII MTs Proyek Kandepag Medan Tahun Pembelajaran dikategorikan baik.

\section{SIMPULAN}

Berdasarkan hasil penelitian yang telah diuraikan, dapat disimpulkan kemampuan menceritakan kembali cerita anak oleh siswa kelas VII MTs Proyek Kandepag Medan Tahun Pembelajaran dalam kategori "Baik" karena 36 siswa (48\%) memperoleh nilai antara 66-79 dengan nilai rata-rata 70 . Berdasarkan kesimpulan yang telah dikemukakan, peneliti memberikan beberapa saran dalam upaya meningkatkan prestasi belajar siswa sebagai berikut:

1. Bagi guru bahasa Indonesia hendaknya sering memberikan latihan kepada siswa terutama latihan menceritakan kembali cerita anak.

2. Kepada siswa disarankan agar mengulang kembali pelajaran yang telah diberikan guru serta rajin dan sungguh-sungguh dalam belajar sehingga mampu memahami pelajaran yang telah diberikan oleh guru.

3. Belajar siswa diharapkan mampu menguasai materi yang diberikan oleh guru agar pembelajaran berlangsung dengan baik. 
DAFTAR PUSTAKA

Ali, Muhammad. 1987. Penelitian Kependidikan dan Strategi. Bandung :Angkasa

Amri, Sofan. 2013. Pengembangan \& Model Pembelajaran dalam Kurikulum 2013. Jakarta : Prestasi Pustaka Publisher

Arikunto, Suharsimi. 2013. Prosedur Penelitian Suatu Pendekatan Praktik. Jakarta : Rineka Cipta.

Depdiknas. 2007. Kamus Besar Bahasa Indonesia. Jakarta : Gramedi

Depdiknas (http://ngasukaweruh.blogspot. co.id/2013/08/materi-menceritakan -kembali-cerita-anak.html)

Kurniawan, Heru. 2009. Sastra Anak dalam Kajian Strukturalisme, Sosiologi,

Semiotika, hingga Penulisan Kreatif. Yogyakarta : Graha Ilmu.
Mursini. 2010. Bimbingan Apresiasi Sastra Anak-Anak. Medan : USU Pers.

Nurhadi, dkk. 2007. Penuntun Pelajaran Bahasa Indonesia. Jakarta : Erlangga

Sugiyono. 2009. Metode Penelitian Pendidikan Pendekatan Kuantitatif, Kualitatif, dan $R \& D$. Bandung : Alfabeta.

Tarigan, Henry Guntur. 2010. Berbicara Sebagai Suatu Keterampilan Berbahasa. Bandung : Angkasa.

Tarigan, Henry Guntur. 1986. Teknik Pengajaran Keterampilan Berbahasa. Bandung : Angkasa.

Http://pgsdduty.blogspot.co.id/2014/06/sas tra-anak.html 